\title{
How unfair is cross-community consent? Voting power in the Northern Ireland Assembly
}

\author{
Alex SCHWARTZ* \\ Queen's University Belfast
}

$\mathrm{R}$ ick Wilford astutely describes the system of government in Northern Ireland as "parliamentary life, but not quite as we know it". ${ }^{1}$ Naturally, the "we" here refers to those of us who are most familiar with the Westminster model of parliamentary democracy. Undeniably, many of the features of the Westminster model are either absent or barely recognisable in Northern Ireland. ${ }^{2}$ Perhaps most fundamentally, the "constitution" of Northern Ireland does not concentrate public power in the hands of transient electoral victors. Instead, the scheme seeks to include all major political factions within a broad power-sharing coalition. Thus, in contrast to Westminster-style majority rule, most commentators agree that the system of government in Northern Ireland is an example of "consociational" democracy. ${ }^{3}$

One of the central elements of Northern Ireland's consociational framework is the idea of "cross-community support". That principle has (at least) two dimensions. On the one hand, the representational legitimacy of public authorities, ranging from the Police Service of Northern Ireland, the Parades Commission, the Commission for Victims and Survivors, to the Northern Ireland Human Rights Commission, is frequently understood (or contested) in terms of cross-community support. ${ }^{4}$ On the other hand, the idea of crosscommunity support finds concrete expression in the decision-making procedures of the Northern Ireland Assembly where, with respect to certain "key" decisions, crosscommunity "consent" is a formal procedural requirement. ${ }^{5}$

I am indebted to Moshé Machover, John McGarry, and Rick Wilford for helpful comments on earlier drafts of this article.

1 R Wilford, "Northern Ireland: the politics of constraint" (2010) 63 Parliamentary Affairs 134, at 137.

2 Ibid. pp. 137-40.

3 See D Horowitz, "The Northern Ireland Agreement: clear, consociational and risky" in J McGarry (ed.), Northern Ireland and the Divided World (Oxford: OUP 2001); see also R Taylor "Introduction" in R Taylor (ed.), Consociational Theory (Oxon: Routledge 2009); and B O'Leary “The nature of the Agreement" (1999) 4 Fordham Journal of International Law 22. For a dissenting interpretation, see P Dixon, "Why the Good Friday Agreement in Northern Ireland is not consociational" (2005) 76 Political Quarterly 357.

4 See G Anthony "Judicial review in Northern Ireland: a guide to the 'real' devolution issues" (2009) 14 Judicial Review.

5 Agreement reached in multiparty talks (The Agreement), Strand One, para. 5(d). 
The apparent "group-think" of the cross-community consent procedures would seem to challenge the individualistic suppositions of liberal constitutionalism. ${ }^{6}$ The procedures require that, upon taking their seats, members of the Assembly (MLAs) register a "community designation" as "unionist", "nationalist", or "other". 7 When the crosscommunity consent procedures are activated, designated unionists and nationalists enjoy a potential veto power that designated others do not. Not surprisingly, the cross-community consent procedures have been the subject of vociferous criticism, not only from the academic community, ${ }^{8}$ but also from the Alliance Party, which, as designated others, argues that the procedures unfairly discriminate against it. ${ }^{9}$ In effect, so the argument goes, the procedures make it "more rewarding to be a member of one of the two named national communities". 10

As we shall see, there is some basis to this line of criticism. Thus far, however, the debate about the cross-community consent procedures has transpired at a very general level. I hope to advance the conversation here by showing precisely how the procedures impact voting power within the Assembly. This should help to correct vague notions about the unfairness of the procedures. As we shall see, the critics overstate their case: in practice, "others" are not necessarily any more (or less) disadvantaged than designated unionists and nationalists. Moreover, I argue that cross-community consent is a valuable mechanism for managing the constitutional politics of Northern Ireland in an appropriately nonmajoritarian way.

\section{The unfairness of the cross-community consent procedures}

The basic aim behind the cross-community procedures is to prevent a simple majority of the Assembly from passing decisions without a critical amount of support from both national blocs. Hence, certain key decisions, such as standing orders and budget allocations, require either at least a majority of designated unionists and nationalists, as well as a majority in the Assembly, or, in the alternative, a weighted majority of at least 60 per cent of members present and voting, including at least 40 per cent each of designated unionists and nationalists present and voting. ${ }^{11}$ Moreover, any Assembly decision may be subjected to the cross-community consent rules where a "Petition of Concern" is brought by at least 30 MLAs. ${ }^{12}$

Arguably, the cross-community decision procedures protect each community from being politically dominated by the other. But even if one grants that unionists and nationalists ought to enjoy some kind of counter-majoritarian protection against each other, the cross-community procedures paradoxically appear to purchase that protection at the expense of those who do not identify with either community. As Rick Wilford argues:

6 See I O'Flynn, “The problem of recognising individual and national identities: a liberal critique of the Belfast Agreement" (2003) 6 Critical Review of International Social and Political Philosophy 129. On the general tension between liberal constitutionalism and group-rights, see J Habermas, "Struggles for recognition in the democratic constitutional state" in A Gutmann (ed.), Multiculturalism: Examining the politics of recognition (Princeton: Princeton UP 1994).

7 Northern Ireland Act 1998, s. 4(5).

8 See, for example, Wilford, "Northern Ireland", n. 1 above; D Horowitz, "Explaining the Northern Ireland Agreement: the sources of an unlikely constitutional consensus" (2002) 32 British Journal of Political Science 193; and O'Flynn, "The problem", n. 6 above.

9 Alliance Party of Northern Ireland, Submission to the NI Assembly Voting System and MLA Designations Review $1 / 11 / 2001$.

10 O'Flynn, "The problem”, n. 6 above, p. 144.

11 See Northern Ireland Act 1998, ss. 4(2A), 4(3), 4(5), 17, 28A(4(a)), 30, 39, 41 and 63(3).

12 Ibid. s. 42. 
In effect, there are two orders of Assembly members: in relation to key decisions there are those whose votes always "count" and those whose votes never do so. Not only is this patently undemocratic, in the particular case of the Alliance Party it is also richly ironic. Since its inception, it has been bi-confessional and committed to the promotion of positive cross-community relations and yet it is a casualty of this anomalous and wholly unnecessary procedure which could easily be surrendered in favour of weighted majority voting on key issues. ${ }^{13}$

Intuitively, this does seem unfair. But we need to be careful about drawing hasty or general conclusions here. Critics tend to overstate the differential impact of the procedures on designated others. Wilford, for one, certainly gives the wrong impression when he says that the votes of others never count. In fact, the votes of others always count - they count towards the majority (or supermajority) threshold. Similarly, Ian O'Flynn argues that 'in practice the parallel consent rule implies that once a majority is secured within the assembly, the 'others' no longer count; at such a point, all that matters is whether or not there is a majority within both communities". ${ }^{14}$ Again, this is a very misleading way of characterising the crosscommunity consent procedures. It is true that once a majority is secured in a cross-community vote, the votes of others no longer count. But it is equally true that under a simple-majority decision the votes of others do not count once a majority is otherwise secured.

Perhaps what critics like Wilford and O'Flynn really mean to say is that the votes of designated unionists and nationalists are more decisive than the votes of designated others. This much is suggested by the Alliance Party in its 2001 submissions to the Review of the Northern Ireland Assembly. ${ }^{15}$ As the Alliance Party points out, the cross-community consent procedures effectively count the votes of designated unionists and designated nationalists twice - first with respect to the overall threshold in the Assembly, and again with respect to the community designation thresholds. ${ }^{16}$ So, in so far as the votes of others may be necessary to meet the majority or supermajority thresholds, their votes are not, strictly speaking, irrelevant. However, on a cross-community vote, the votes of designated unionists and nationalists are more likely than the votes of others to have a determinative effect on the outcome. This line of argument, at least, suggests a more precise way of formulating the problem.

The disadvantage suffered by designated others, understood in terms of the relative decisiveness of their votes, can actually be quantified by calculating and comparing the voting power of each party in the Assembly on a simple-majority decision against their respective voting power under the cross-community consent procedures. As we shall see, such an analysis substantiates, in mathematical terms, the moral intuition that the crosscommunity rules are unfair to others. But the same analysis also reveals that the rules do not unfairly disadvantage others vis-à-vis unionists and nationalists per se. Rather, the crosscommunity rules tend to enhance the voting power of the two largest community designation parties at the expense of all other parties, including the smaller community designation parties. In other words, the rules tend to be unfair to smaller parties, regardless of community designation. Moreover, designated others are not necessarily the most disadvantaged by the cross-community consent procedures - on occasion the rules can be even more unfair to smaller community designation parties.

13 Wilford, "Northern Ireland", n. 1 above, p. 139.

14 O’Flynn, “The problem”, n. 6 above, p. 144.

15 Alliance Party, Submission, n. 9 above.

16 Ibid. para. 2.2.4. 


\section{Measuring voting power}

It is perhaps too optimistic to hope that real-world democratic politics will ever be perfectly fair. From the outset, power relations tend to inhibit the realisation of free and equal discursive engagement. ${ }^{17}$ But we can at least scrutinise the fairness of the procedures that regulate politics. Here, we are specifically concerned with how the procedures in the Assembly affect the voting power of its MLAs. This question is distinct from the actual voting power of MLAs. To be sure, the Assembly's procedures inevitably have an effect on actual voting power, but they do not exhaustively determine it. The actual voting power of MLAs is a much more complex question. It depends on any number of empirical factors, including, inter alia, the diplomatic skill of individual MLAs, the compatibility and intensity of their respective preferences, the particular issues that happen to dominate the agenda at a given time, and changing party alliances and rivalries. ${ }^{18}$ Because the argument that concerns us here relates to the fairness of the procedures themselves, we need only focus on that element of actual voting power that derives solely from those procedures. In other words, we are interested in a priori voting power - "the power that a member derives exclusively from the decision rule itself". 19

As Felsenthal and Machover explain, a priori voting power can be conceptualised in two distinct ways. The first of these is what they call "I-power": "a voter's potential influence over the outcome of divisions of the decision-making body - whether proposed bills are adopted or blocked." 20 I-power is to be distinguished from what they call "P-power": "a voter's expected relative share in a fixed prize available to the winning coalition under a decision rule". ${ }^{21}$ I-power understands voting in terms of the passage or defeat of bills. Voting behaviour is therefore motivated by "policy-seeking". Conversely, P-power understands the outcome of a vote in terms of the distribution of some set of goods ("transferable utility") to be divided by the victors among themselves. P-power can be measured by the Shapley-Shubik index, a type of voting power analysis derived from cooperative game theory. ${ }^{22}$ The Shapley-Shubik index equates voting power with a voter's expected pay-off in a cooperative game where a fixed amount of transferable utility is to be shared among victors of a winning coalition according to "a prior binding agreement, arrived at through bargaining, and concluded in advance of the decision". ${ }^{23}$ This gametheoretic model of voting power may have some distinctive applications, but it is not generally applicable to legislative decision-making. ${ }^{24}$ In such cases, voting is primarily about determining a common course of action on behalf of a decision-making body. ${ }^{25}$ Collective decisions of this kind may or may not have consequences that are intelligible in terms of transferable utility. ${ }^{26}$ Since we are concerned here with how the rules affect the ability of voters to influence the outcome of decisions in the Assembly (and not with the pay-offs they might expect as a result), we will ignore P-power and concentrate solely on I-power. In

17 See, generally, J Habermas, The Theory of Communicative Action (London: Heinemann 1984).

18 See D Felsenthal and M Machover, “A priori voting power: what is it all about?" (2004) 2 Political Studies Review 13.

19 Ibid. p. 14.

20 Ibid.

21 Ibid.

22 LS Shapley and M Shubik, "A method for evaluating the distribution of power in a committee system" (1954) 48 American Political Science Review 787.

23 Felsenthal and Machover, "A priori voting power", n. 18 above, p. 8.

24 See ibid. p. 10.

25 Ibid.

26 Ibid. p. 12. 
what follows, all references to "a priori voting power" (or even just "voting power") will therefore refer exclusively to I-power and not P-power.

\section{Penrose and Banzhaf}

The a priori voting power of a voter in a decision-making body can be understood in terms of the probability that the voter's vote will be decisive in a binary decision (a "yes" or "no" decision on a bill or motion). So understood, a priori voting power is measured by the Penrose index $(\psi)$. The Penrose index assumes that all possible divisions of "yes" and "no" votes are equally probable. In other words, it is assumed that any voter is just as likely to vote "yes" as to vote "no", regardless of how the other voters vote. An assembly of n members therefore yields $2^{n}$ possible divisions of "yes" and "no" votes. Voter "a" is decisive in those divisions where a's vote could convert an otherwise winning coalition into a losing one or an otherwise losing collation into a winning one. In such cases, a has a "swing vote". The proportion of all possible divisions in which a has a swing vote yields $\psi_{\mathrm{a}}$ :

$\Psi_{\mathrm{a}}=$ a's swing votes $/ 2^{\mathrm{n}}$ possible divisions

Accordingly, $\Psi_{\mathrm{a}}$ represents a's voting power understood as the "a priori probability that, in a division on a bill, the votes will be so disposed that if a's vote were to be reversed then the fate of the bill would also be reversed". ${ }^{27}$

The Penrose index expresses a probabilistic measurement of voting power in absolute terms. But for some purposes it may be useful to measure how much voting power voters have relative to one another. Relative a priori voting power is measured by the Banzahf index $(\beta) .{ }^{28} \beta_{\mathrm{a}}$ is simply $a$ 's proportion of all possible swing votes. Alternatively, if $\psi$ is known for all voters, $\beta_{\mathrm{a}}$ can be easily derived from $\psi_{\mathrm{a}}$ as follows:

$$
\beta_{\mathrm{a}}=\psi_{\mathrm{a}} /\left(\psi_{\mathrm{a}}+\psi_{\mathrm{b}}+\psi_{\mathrm{c}}+\psi_{\mathrm{d}}\right)
$$

It should be noted that, because the Banzahf index measures the relative share of total voting power, the total $\beta$ indices of all voters will always equal 1 . It should also be noted that, while there is a relation between absolute and relative voting power, a gain or loss in $\psi$ does not necessarily entail a corresponding gain or loss in $\beta$.

\section{Voting power simulations}

The following voting power analysis makes use of "simulations". These simulations are intended to illustrate the differential impact of the cross-community consent procedures. They are not intended to accurately depict reality. Thus, the simulations make a few counterfactual assumptions in the interests of simplicity. First of all, the Northern Ireland Assembly has 108 members. This means that there are $2^{108}$ possible divisions. Calculating the a priori voting power of each individual MLA in these terms is not only exceedingly complicated; it is also of little value since it takes no account of MLAs being organised along party lines. So, for the sake of simplicity (and a little realism), the following calculations concern the voting power of parties (not individual MLAs), on the assumption that parties vote as blocs. This is not an altogether unrealistic assumption. ${ }^{29}$ In any case, it helps to simplify matters considerably. The simulations also treat all designated others as if they formed a single party (the Others Coalition, or OC) and it is assumed that the Others Coalition also votes as a bloc. This is less realistic. While the three parties designated as

27 See D Felsenthal and M Machover, The Measurement of Voting Power (Cheltenham: Edward Elgar 1998), p. 40.

28 See J Banzhaf, "Weighted voting doesn’t work: a mathematical analysis” (1965) 19 Rutgers Law Review 317.

29 On intra-party cohesion and division, see J Tonge and J Evans, "Party members and the Good Friday Agreement in Northern Ireland" (2002) 17 Irish Political Studies 59. 
other currently holding seats in the Assembly - the Alliance Party, the Green Party and the Independent Health Coalition - have worked together for some purposes under the umbrella of the United Community Group (UCG), they are distinct political parties, each with its own policy preferences. Nevertheless, since we are concerned here with the voting power of designated others qua others, it helps to imagine the others as forming a cohesive coalition. This allows us to conceptualise their collective voting power vis-à-vis the collective voting power of designated unionist and nationalist parties. A final simplification here is the exclusion of the independent unionists from the simulations. This undoubtedly distorts the results, since even a single seat can be a decisive vote on occasion. But the addition of $\mathrm{n}$ parties increases the possible divisions by $2^{\mathrm{n}}$ without necessarily helping to illuminate the fairness of the decision rules in question. In the interests of simplicity then, all simulations imagine that their are no independent unionist (or nationalist) seats. The different decision procedures - simple majority, parallel consent, and weighted majority are respectively abbreviated as SM, PC and WM. The associated overall, unionist, and nationalist quotas for each procedure are shown within "curly" brackets in the simulation tables reproduced below.

Simulations A and B are very simple: in both simulations the Assembly is composed of only three (imaginary) parties, the Unionist Party (UP), the Nationalist Party (NP) and the OC. This yields $2^{3}$ possible divisions (i.e. eight). In Simulation A (Table 1.1), the UP and the NP each have 26 seats and the OC holds the remaining 56 seats. In Simulation B (Table 1.2), the same three parties are in play, but this time each holds 36 seats in the Assembly.

The simulations help to illustrate a few mathematical rules that derive purely from the operation of the cross-community decision procedures. In order to describe these rules, it is useful to divide the Assembly into "sets". So, let $P$ be the set of all parties in the assembly; $P=\left\{p_{1}, p_{2} \ldots, p_{n}\right\}$. Similarly, let $U$ be the set of all unionist parties, let $N$ be the set of all nationalist parties, and let $O$ be the set of all designated others. Finally, let $C$ be the set of all designated nationalists and unionists, such that $C=U+N$.

Table 1.1: Simulation A

\begin{tabular}{|c|c|c|c|c|c|c|}
\hline $\begin{array}{l}\text { UP } \\
\text { (26) }\end{array}$ & $\begin{array}{l}\text { NP } \\
(26)\end{array}$ & $\begin{array}{c}O C \\
(56)\end{array}$ & $\begin{array}{l}\text { Total votes } \\
\text { (Us, Ns) }\end{array}$ & $\begin{array}{c}\text { Swing voters } \\
\text { SM } \\
\{55\} \\
\end{array}$ & $\begin{array}{c}\text { Swing voters } \\
\text { PC } \\
\{55 ; 14 ; 14\} \\
\end{array}$ & $\begin{array}{c}\text { Swing voters } \\
\text { WM } \\
\{65 ; 11 ; 11\} \\
\end{array}$ \\
\hline$Y$ & Y & $Y$ & $108(26,26)$ & $O C$ & $U P, N P, O C$ & UP, NP, OC \\
\hline$Y$ & Y & $N$ & $52(26,26)$ & $O C$ & $O C$ & $O C$ \\
\hline Y & $N$ & Y & $82(26,0)$ & $O C$ & $N P$ & $N P$ \\
\hline Y & $N$ & $N$ & $26(26,0)$ & $O C$ & - & - \\
\hline$N$ & Y & $Y$ & $82(0,26)$ & $O C$ & UP & UP \\
\hline$N$ & Y & $N$ & $26(0,26)$ & $O C$ & - & - \\
\hline$N$ & $N$ & $Y$ & $56(0,0)$ & $O C$ & - & - \\
\hline$N$ & $N$ & $N$ & $0(0,0)$ & $O C$ & - & - \\
\hline
\end{tabular}


Now, as Simulation A shows, under an SM decision rule it is possible for a party to be a "dictator" $\left(\psi_{\mathrm{p}}=1\right)$. Thus, because OC has a majority of seats in Simulation A, there is a 100 per cent probability that the votes of the OC will be decisive $\left(\psi_{\mathrm{O}}=1\right)$. This illustrates the general proposition that if $p$ holds a majority of seats in the Assembly, then $p$ is a dictator. This proposition can be expressed as follows, where "s $p$ " refers to the number of seats held by any party $p$, and "s $P$ " refers to the total number of seats held by all parties $(P)$ :

For any $\mathrm{SM}$ decision rule, $\mathrm{s}_{p}>\mathrm{s} P \times 0.5 \rightarrow \psi \mathrm{p}=1$

Under both of the cross-community decision rules, however, no party can ever enjoy more than a 50 per cent probability that its vote will be decisive $\left(\Psi_{\mathrm{p}} \leq 0.5\right)$ because no party can ever form a winning coalition without the contribution of at least one other party (nationalists cannot win without unionists; unionists cannot win without nationalists; and others cannot win without some nationalists and some unionists). Thus, unlike the SM decision rule, the cross-community decision rules preclude the possibility of a dictator. This can be seen in Simulation A, where a winning coalition under the cross-community procedures necessarily includes all three parties, and in Simulation B, where a winning coalition necessarily includes at least two parties.

However, although the cross-community procedures require that a winning coalition necessarily includes at least some unionists and some nationalists, there is no such requirement with respect to others. Indeed, where the votes of others are not needed to meet the majority threshold, the cross-community rules have the effect of reducing their voting power to 0 . This can be seen in Simulation B. There, the votes of the unionist and nationalist parties are both necessary and sufficient to carry their respective community quotas and both parties together have more than enough votes to carry the overall majority quota (and even the overall WM quota). In other words, the votes of both community designation parties are necessary and sufficient for any possible winning coalition. Conversely, the OC is neither necessary nor sufficient for any winning coalition. The OC's Penrose index is therefore 0 .

Table 1.2: Simulation B

\begin{tabular}{|c|c|c|c|c|c|c|}
\hline $\begin{array}{l}\text { UP } \\
\text { (36) }\end{array}$ & $\begin{array}{l}\mathrm{NP} \\
(36)\end{array}$ & $\begin{array}{c}O C \\
(36)\end{array}$ & $\begin{array}{c}\text { Total votes } \\
\text { (Us, Ns) }\end{array}$ & $\begin{array}{c}\text { Swing voters } \\
\text { SM } \\
\{55\} \\
\end{array}$ & $\begin{array}{c}\text { Swing voters } \\
\text { PC } \\
\{55 ; 19 ; 19\} \\
\end{array}$ & $\begin{array}{c}\text { Swing voters } \\
\text { WM } \\
\{65 ; 15 ; 15\} \\
\end{array}$ \\
\hline Y & $Y$ & Y & $108(36,36)$ & - & $U P, N P$ & $U P, N P$ \\
\hline Y & $Y$ & $N$ & $72(36,36)$ & $U P, N P$ & $U P, N P$ & $U P, N P$ \\
\hline Y & $N$ & Y & $72(36,0)$ & $U P, O C$ & $N P$ & $N P$ \\
\hline Y & $N$ & $N$ & $36(36,0)$ & $N P, O C$ & $N P$ & $N P$ \\
\hline$N$ & $Y$ & Y & $72(0,36)$ & $N P, O C$ & UP & UP \\
\hline$N$ & Y & $N$ & $36(0,36)$ & $U P, O C$ & UP & UP \\
\hline$N$ & $N$ & Y & $36(0,0)$ & $U P, N P$ & - & - \\
\hline$N$ & $N$ & $N$ & $0(0,0)$ & - & - & - \\
\hline
\end{tabular}


The unfairness apparent in the above simulations can be quantified in terms of the differential impact of the cross-community procedures on the possible voting power of others. Although the procedures limit the possible voting power of all parties, the possible voting power of others is limited to a greater extent. In effect, the procedures yield two different voting power "ceilings" - one for unionists and nationalists $\left(\psi_{c} \leq 0.5\right)$, and another for others $\left(\psi_{o} \leq 2.5\right)$. The difference between these two ceilings captures, in an abstract way, the inherent unfairness of the cross-community procedures.

In practice, however, the effects of the cross-community decision procedures are significantly more complicated. Simulation $C$ helps to illustrate this point. Simulation C contemplates an Assembly not unlike the one elected in 2007: the Democratic Unionist Party (DUP) has 36 seats, Sinn Féin (SF) has 28 seats, the Ulster Unionist Party (UUP) has 18 seats, the Social Democratic and Labour Party (SDLP) has 16 seats, and the hypothetical OC has 10 seats. An Assembly composed of five parties (each presumed to vote as blocs) yields $2^{5}$ (i.e. 32) possible divisions (see Appendix A on page 362 below). The impact of the PC rule is apparent (see Table 2).

The DUP has more than enough votes to carry the unionist quota of 28 and SF has more than enough votes to carry the nationalist quota of 23. Moreover, both parties together have more than enough votes to carry the SM quota of 55. Thus, out of 32 possible divisions, the DUP and SF have 16 swing votes each (SF's vote is decisive whenever the DUP votes "yes" and the DUP's vote is decisive whenever SF votes yes). Hence, the Penrose index for both the DUP and SF is 0.5 , meaning that each enjoys a 50 per cent probability that their vote will be a decisive one. Conversely, the other three parties are never decisive (the Penrose indices for all three other parties is 0). Because the DUP and SF are the only two parties to have any swing votes, their Banzhaf scores are 0.5 each, indicating that each party enjoys 50 per cent of the relative voting power under the PC rule. In short, the rule makes the DUP and SF "co-dictators" - the votes of both parties are necessary and sufficient for the formation of any possible winning coalition. Conversely, the votes of the UUP, the SDLP and the OC are all "dummy" votes - they have no decisive impact one way or the other.

Table 2: Voting power for Simulation C

\begin{tabular}{cccccc}
\hline $\begin{array}{c}\text { Decision } \\
\text { procedure }\end{array}$ & DUP (36) & SF (28) & UUP (18) & SDLP (16) & OC (10) \\
\hline SM \{55\} & & & & & \\
swings & 18 & 14 & 10 & 6 & 6 \\
Penrose $(\boldsymbol{\Psi})$ & 0.563 & 0.438 & 0.313 & 0.188 & 0.188 \\
Banzhaf $(\boldsymbol{\beta})$ & 0.33 & 0.26 & 0.19 & 0.11 & 0.11 \\
PC $\{55 ; 28 ; 23\}$ & & & & & \\
swings & 16 & 16 & 0 & 0 & 0 \\
Penrose $(\boldsymbol{\Psi})$ & 0.5 & 0.5 & 0 & 0 & 0 \\
Banzhaf $(\boldsymbol{\beta})$ & 0.5 & 0.5 & 0 & 0 & 0 \\
WM $\{65 ; 22 ; 18\}$ & & & & & \\
swings & 14 & 14 & 2 & 2 & 2 \\
Penrose $(\boldsymbol{\Psi})$ & 0.438 & 0.438 & 0.063 & 0.063 & 0.063 \\
Banzhaf $(\boldsymbol{\beta})$ & 0.41 & 0.41 & 0.06 & 0.06 & 0.06 \\
\hline
\end{tabular}


The results are similar under the WM rule. Once again the votes of both the DUP and SF are both necessary and sufficient to carry their respective unionist and nationalist quotas. However, the two parties together do not have sufficient combined weight to meet the 60 per cent WM threshold. For that they need to enlist the help of one (and only one) other party. This gives the other parties some impact that they would not have under the PC rule discussed above - out of 32 possible divisions, each of the other parties has two swing votes each (a "yes" swing and a "no" swing) and their Penrose indices accordingly are 0.063 (as opposed to 0$)$.

A comparison of the resultant voting power for each party against its voting power under the SM rule shows that the cross-community procedures are not necessarily more unfair to others. ${ }^{30}$ On the contrary, in Simulation C, the cross-community procedures are equally unfair to the SDLP and the OC. Moreover, the procedures are even more unfair to the UUP - it suffers the greatest total loss in both absolute and relative voting power. The clear winner in the cross-community procedures is SF. Under the PC rule, SF is 14 per cent stronger in absolute terms and 92 per cent stronger in relative terms (almost twice as strong). Similarly, the weighted majority rule is fair to SF in absolute terms, but favourable in terms of relative voting power. The results for the DUP are more ambiguous - under both the PC and WM rules the DUP is weaker in terms of absolute voting power. But the unfairness to the DUP in terms of absolute voting power is arguably counterbalanced by its substantial gains in relative voting power - the DUP becomes 51.5 per cent stronger under the PC rule and 24 per cent stronger under the WM rule.

Idiosyncrasies aside, the general point to take away here is that the cross-community rules tend to be unfair to all smaller parties - nationalists, unionists and others alike. This is not an accidental artefact of the particular distribution of party strengths in Simulation C: it is a general feature of the cross-community consent procedures whenever there is a larger unionist party and a larger nationalist party such that the larger unionist party's voting weight is sufficient to meet the unionist quota and the larger nationalist party's voting weight is sufficient to meet the nationalist quota. In all such cases, the cross-community decision rules will be unfair to all other parties, regardless of community designation. ${ }^{31}$

The foregoing analysis identifies two aspects of the unfairness inherent in the crosscommunity rules. On the one hand, the rules are specifically unfair to others in so far as they impose upon them a lower ceiling of possible voting power. On the other hand, the rules tend to be unfair to any smaller party, regardless of community designation. The question to be addressed in what follows is whether or not this unfairness is mitigated by other considerations.

\section{Constitutional politics and super-legitimacy}

While the preceding discussion helps to clarify the unfairness inherent in the crosscommunity decision rules, it also risks obscuring something important about those rules: whether or not the cross-community decision procedures apply, the Assembly cannot pass a motion or Bill without at least a majority of MLAs in favour of the same. Thus, the legitimacy of any successful motion or Bill within the Assembly is always, at least partially,

30 This assumes, of course, that a simple majority decision procedure represents an abstract or formal benchmark standard of fairness. On that assumption, a party is treated "fairly" by a deviation from the SM rule where its voting power remains the same. A party is treated "unfairly" if it suffers a loss in voting power. A party is treated "favourably" if it gains in voting power.

31 Indeed, if the combined voting weight of the larger unionist party and the largest nationalist party is also greater than or equal to the overall quota for the decision procedure in question, then the Penrose and Banzhaf indices for all other parties will be exactly 0 . 
derived from the consent of the majority. The difference the cross-community procedures make is that certain decisions require a degree of "super-legitimacy" beyond that which is conferred by an SM. So, whatever differential impact on voting power the cross-community decision procedures may have, the procedures also have the more general effect of making it more difficult to execute certain types of collective action.

It is not uncommon for some matters to be singled out and subjected to especially onerous decision procedures. The quintessential example in constitutional law is, of course, constitutional amendment. Typically, constitutions cannot be changed except by way of some special amendment formula. Amendment formulae may variably require such special measures as the approval of a super-majority in the legislature, the approval of consecutive legislatures, or ratification by popular referenda. ${ }^{32}$ In federal systems, constitutional amendment may also require the consent of some or all of the constituent territories. ${ }^{33}$ In any case, formal amendment processes tend to have the general effect of making constitutional change more difficult to realise than ordinary legislation. ${ }^{34}$

The justification for onerous amendment formulae is often explained in terms of constitutional "pre-commitment". 35 The idea is that the "people" collectively bind themselves to certain fundamental principles or rules so as to guard against the temptation to depart from those fundamentals when subsequent events strain their collective commitments. ${ }^{36}$ To be sure, the possibility of constitutional amendment allows that the people may later resolve to alter their fundamental laws. In some cases, as Bruce Ackerman argues, sustained and popular "mobilized deliberation" may even succeed in effecting constitutional change without recourse to formal amendment procedures. ${ }^{37}$ But such instances of "higher lawmaking", whether by formal amendment or popular mobilisation, occur "rarely, and under special constitutional conditions". 38 In contrast to the everyday politics of ordinary lawmaking, higher lawmaking is an extraordinary and onerous process, the peculiar product of "constitutional politics" at exceptional "constitutional moments". 39

In a plurinational context, however, processes of constitutional change have an added significance. As Sujit Choudhry explains, in multinational polities, "constitutional politics" has two dimensions:

On the one hand, there is the sort of constitutional politics that presupposes the existence of a national political community. But in parallel - and simultaneously - multinational polities also engage in constitutive constitutional politics, which concern existential questions that go to the very identity, even existence, of the political community as a multinational political entity. ${ }^{40}$

32 See D Lutz, “Toward a theory of constitutional amendment” (1994) 88 American Political Science Review 355.

33 E.g. Canada's Constitution Act 1982, s. 38(1).

34 Lutz, "Toward a theory", n. 32 above, pp. 360-2.

35 See, generally, J Elster, Ulysses Unbound (Cambridge: CUP 2000), ch. 2.

36 On the tension between democracy and constitutional pre-commitment, see S Holmes "Precommitment and the paradox of democracy" in J Elster and R Slagstad (eds), Constitutionalism and Democracy (Cambridge: CUP 1998); see also M Laughlin and N Walker (eds), The Paradox of Constitutionalism: Constituentponver and constitutional form (Oxford: OUP 2007).

37 See B Ackerman, We the People: Foundations (London: Belknap Press 1993), pp. 7 and 285-8.

38 B Ackerman, "Constitutional politics/constitutional law" (1989) 99 Yale Law Journal 461.

39 B Ackerman, "Revolution on a human scale" (1999) 108 Yale Law Journal 2279.

40 S Choudhry, "Does the world need more Canada? The politics of the Canadian model in constitutional politics and political theory" (2007) 5 International Journal of Constitutional Law 606, pp. 635. 
In such cases, processes of constitutional change are not neutral as between competing substantive preferences. ${ }^{41}$ The processes themselves invariably reflect a particular conception of the polity, one in which the power to effect constitutional change resides in a single national demos or one in which constituent power is shared between multiple demoi. ${ }^{42}$ It is typical then for sub-state national groups to challenge monistic conceptions of the polity and insist that the processes of constitutional change occur "on the basis of parity between or among national societies within the state, particularly where rights or prerogatives of the sub-state society are affected by the constitutional changes in question". ${ }^{43}$ The image then is not of a single people deciding on a common set of principles once and for all, but that of a plurality of "peoples" who continue to negotiate norms of mutual recognition in perpetuity. ${ }^{44}$

Constitutional politics in Northern Ireland raises similar constitutive issues concerning the identity of the polity and constitutional change, but the challenges it poses are significantly more complex. To begin with, the temporal border between regular politics and constitutional politics in Northern Ireland is especially indeterminate - constitutionalism in Northern Ireland is still very much "transitional" in nature. ${ }^{45}$ Thus, although the Belfast Agreement provides a framework for managing the constitutive constitutional politics of Northern Ireland in a peaceful way, it does not purport to finally resolve it. ${ }^{46}$ Instead, constitutional change in Northern Ireland has been (and still is) an ongoing process in which incremental changes, such as the St Andrews Agreement or the recent Hillsborough Agreement, have played a critical role. ${ }^{47}$ Secondly, and perhaps more importantly, there is no clear substantive border between regular politics and constitutional politics in Northern Ireland. Alongside the high politics of Northern Ireland's ultimate constitutional destiny, there are a range of lesser issues that, although not constitutional in the strict sense, nevertheless have an indirect constitutional significance in so far as they concern the constitutional identity of the polity or the viability of its power-sharing style of government. Thus, decisions concerning the public display of political symbols, the composition of public authorities, the regulation of contentious parades, and the election of the First and Deputy First Ministers all have a quasi-constitutional importance in Northern Ireland that comparable decisions would not have in a more normal society. In short, because there is no bright line between regular politics and constitutive constitutional politics in Northern Ireland, the system of government is under a far-reaching and seemingly indefinite burden to legitimate itself.

The cross-community decision procedures provide a way of managing the ongoing constitutional politics of Northern Ireland by requiring a degree of super-legitimacy for decisions of special constitutional significance. Indeed, the constitutional significance of

41 S Choudhry, "Ackerman's higher lawmaking in comparative constitutional perspective: constitutional moments as constitutional failures?” (2008) 6 International Journal of Constitutional Law 193, pp. 197.

42 S Tierney, "We the peoples: constitution power and constitutionalism in plurinational states" in Laughlin and Walker, The Paradox, n. 36 above.

43 S Tierney, Constitutional Law and National Pluralism (Oxford: OUP 2004), p. 132.

44 J Tully, "Recognition and dialogue: the emergence of a new field" (2004) 7(3) Critical Review of International and Social Philosophy 84-106.

45 On the distinctive characteristics of "transitional constitutionalism", see R Teitel, Transitional Justice (Oxford: OUP 2000), ch. 6.

46 J Morison and M Lynch, "Litigating the Agreement: towards a new judicial constitutionalism for the UK from Northern Ireland?”, in J Morison, K McEvoy and G Anthony (eds), Judges, Transition, and Human Rights (Oxford: OUP 2007), p. 115.

47 See R Wilford, "Northern Ireland: St Andrews - the Long Good Friday Agreement" in J Bradburh (ed.), Devolution, Regionalism, and Regional Development (Oxon: Routledge 2008). 
many of the decisions to which the procedures apply is fairly obvious. Decisions relating to the legislative competencies of the Assembly, the powers and number of ministerial offices, amendments to standing orders, and amendments to the ministerial code have palpable constitutional consequences - they directly concern the substantive or formal properties of Northern Ireland's devolved system of government. Other decisions have a less direct constitutional significance. Budgetary decisions of the Assembly fall into this class. ${ }^{48}$ The quasi-constitutional significance of such decisions derives from their connection to the maintenance of a power-sharing system of government. The model of power-sharing envisioned by the Agreement entails that the Executive will be inclusive of all major political factions within the Assembly. It is further presumed (although not strictly required) that the Executive will be led by a unionist-nationalist diarchy. In other words, it is part of the very logic of the system of government that the Executive should enjoy crosscommunity support. Thus, although budgetary decisions are not strictly speaking constitutional - they do not affect the formal or substantive properties of the system of government - a programme of government that did not enjoy cross-community support would undermine the purposes of the constitutional settlement. The requirement that budgetary decisions be passed on the basis of cross-community consent therefore provides an extra guarantee that the system of government will not degenerate into unilateral majoritarianism. Similarly, the requirement that a decision to exclude a minister or political party from the Assembly be made on the basis of cross-community consent ought to be understood in precisely the same way - as a safeguard against the erosion of inclusive power-sharing. 49

But, because the border between normal politics and constitutional politics in Northern Ireland is porous, it is very difficult to identify matters of constitutional significance in advance. This is why the Petition of Concern is important. Precisely because the Northern Ireland Act does not specify any kind of restriction as to the subject-matter of the decisions that may be the subject of a Petition of Concern, the procedure has proven to be a useful device for identifying and managing matters of constitutional significance as they have arisen. In some cases, the matters subjected to cross-community vote by Petition of Concern have a fairly straightforward constitutional significance. Such cases have included motions relating to the continuance of the institutions set up under the aegis of the Agreement (the North/South Ministerial Council, the Civic Forum, the Northern Ireland Human Rights Commission). ${ }^{50}$ In other cases, the Petition of Concern has been used to block motions relating to contentious issues that, although not of direct constitutional significance, are nevertheless matters of constitutive constitutional politics. These have included the display of Easter lilies within the Assembly, the flying of the Union flag from Northern Ireland government buildings, the eligibility of footballers born in Northern Ireland to play for the Irish Republic, the use of the Irish language in the Assembly, and funding for Irish-medium schools. ${ }^{51}$ Admittedly, the Petition of Concern procedure is open to abuse - MLAs can strategically activate the cross-community consent rules simply to block ordinary legislation or motions that they are opposed to, even where there is no

48 Northern Ireland Act 1998, s. 63.

49 Northern Ireland Act 1998, s. 30.

50 See Northern Ireland Assembly Official Report (Hansard) 9 February 2009 "North/South Ministerial Council”; ibid. 3 February 2009 "Civic Forum"; ibid. 1 October 2001 "Northern Ireland Human Rights Commission".

51 Northern Ireland Assembly Official Report (Hansard) 10 April 2001 "Display of lilies in Parliament buildings"; ibid. 6 June 2000 "Motion on Union flag" (Petition of Concern); ibid. 11 December 2007 "FIFA eligibility proposal”; ibid. 9 October 2007 "Irish language"; ibid. 19 November 2007 "Irish-Medium Club Bank". 
particular reason why the matter in question ought not to be decided by an SM vote. But such cases have been the exception, not the norm. ${ }^{52}$

\section{Conclusion: reform?}

It should be clear by now that the existing cross-community voting procedures entail a kind of trade-off: super-legitimacy is obtained at the cost of some unfairness. This trade-off is not, strictly speaking, a necessary one. As many critics (and even some supporters) of the cross-community consent procedures have argued, the existing procedures could be replaced by a "difference-blind" WM quota. 53 In theory, WM quotas of 60 per cent or 65 per cent could guarantee a kind of de facto cross-community support but without recourse to community designation. Thus, the unfairness to others within the Assembly would be remedied.

Nevertheless, I want to sound a brief cautionary note about the proposed reforms. Voting power is very sensitive to the particular distribution of seats within the Assembly and the adoption of different decision quotas can sometimes have counter-intuitive results. A quota of 60 per cent may indeed entail that a winning coalition will include at least some unionists and some nationalists. However, given the current make-up of the Assembly, this is not a particularly "safe" guarantee of de facto cross-community consent. The 65 per cent WM rule is "safer" in this respect, but it also poses a real risk of making the largest party a quasi-dictator. In Simulation C, for example, without the DUP, the other four parties together have 72 votes, just one vote more than the 65 per cent threshold of 71 votes. Thus, an increase in the DUP's strength by only two seats would make their votes necessary (but not sufficient) to any possible winning coalition. In other words, the DUP would have a veto.

The community designation and voting rules are currently scheduled for review by the Assembly and Executive Review Committee, at which time the merits of alternative procedures are likely to be debated. ${ }^{54}$ The adoption of a 60 per cent or 65 per cent weighted majority quota for key decisions would go some of the way towards alleviating the grievances of the others. Moreover, as the foregoing analysis shows, smaller unionist and nationalist parties also have an interest in reforms of this nature. Nonetheless, the existing procedures have proven to be a valuable way of managing especially divisive issues of constitutional importance. This value should be carefully considered before endorsing reforms that may have unpredictable consequences for the rather delicate balance of power in Northern Ireland.

52 Arguably, the use of the Petition of Concern to block a motion in the Assembly relating to the Department of Energy and Climate Change's advertising campaign "Act on $\mathrm{CO}_{2}$ emissions" and to block a motion denouncing MLAs for holding dual electoral mandates would qualify as "abuses" of the procedure. See Northern Ireland Assembly Official Report (Hansard) 9 February 2009 "North/South Ministerial Council"; ibid. 3 February 2009 "Civic Forum"; ibid. 1 October 2001 "Northern Ireland Human Rights Commission".

53 See for example, Wilford, “Northern Ireland”, n. 1 above; see also J McGarry and B O’Leary, "Power shared after the deaths of thousands", in Taylor, Consociational Theory, n. 3 above; see also Alliance Party, Submission, n. 9 above.

54 See Assembly and Executive Review, "Forward work programme", www.niassembly.gov.uk/ assem_exec/2007mandate/assem_exec_fwp.htm. 
Appendix: Simulation C

\begin{tabular}{|c|c|c|c|c|c|c|c|c|}
\hline $\begin{array}{l}\text { DUP } \\
(36)\end{array}$ & $\begin{array}{l}\text { SF } \\
(28)\end{array}$ & $\begin{array}{l}\text { UUP } \\
\text { (18) }\end{array}$ & $\begin{array}{l}\text { SDLP } \\
(16)\end{array}$ & $\begin{array}{l}O C \\
(10)\end{array}$ & $\begin{array}{c}\text { Total votes } \\
\text { (Us, Ns) }\end{array}$ & $\begin{array}{l}\text { SM } \\
\{55\}\end{array}$ & $\begin{array}{c}P C \\
\{55 ; 28 ; 23\}\end{array}$ & $\begin{array}{c}\text { WM } \\
\{65 ; 22 ; 18\}\end{array}$ \\
\hline$Y$ & $Y$ & $Y$ & $Y$ & $Y$ & $108(54,44)$ & - & DUP, SF & DUP, SF \\
\hline Y & Y & Y & Y & $N$ & $98(54,44\}$ & - & $D U P, S F$ & $D U P, S F$ \\
\hline Y & Y & Y & $N$ & Y & $92(54,28)$ & - & DUP, SF & DUP, SF \\
\hline Y & Y & Y & $N$ & $N$ & $82(54,28)$ & DUP, SF & DUP, SF & DUP, SF, UUP \\
\hline Y & Y & $N$ & Y & Y & $90(36,44)$ & DUP & DUP, SF & DUP, SF \\
\hline Y & Y & $N$ & $N$ & Y & $74(36,28)$ & DUP, SF & DUP, SF & DUP, SF, OC \\
\hline Y & Y & $N$ & Y & $N$ & $80(36,44)$ & DUP, SF & DUP, SF & DUP, SF, SDLP \\
\hline Y & Y & $N$ & $N$ & $N$ & $64(36,28)$ & DUP, SF & DUP, SF & UUP, SDLP, OC \\
\hline Y & N & Y & Y & Y & $80(54,16)$ & DUP & SF & SF \\
\hline Y & $N$ & Y & $Y$ & $N$ & $70(54,16)$ & DUP, UUP, SDLP & SF & SF \\
\hline Y & N & Y & $N$ & Y & $64(54,0)$ & DUP, UUP, OC & SF & SF \\
\hline Y & N & Y & N & N & $54(54,0)$ & $S F, S D L P, O C$ & SF & SF \\
\hline Y & N & N & Y & Y & $62(36,16)$ & DUP, SDLP, OC & SF & SF \\
\hline Y & $N$ & $N$ & N & Y & $46(36,0)$ & $S F, U U P, S D L P$ & SF & SF \\
\hline Y & N & $N$ & Y & $N$ & $52(36,16)$ & SF, UUP, OC & SF & SF \\
\hline Y & N & $N$ & N & N & $36(36,0)$ & SF & SF & - \\
\hline N & Y & Y & Y & Y & $72(18,44)$ & $S F$, UUP & DUP & DUP \\
\hline$N$ & Y & Y & $Y$ & $N$ & $62(18,44)$ & SF, SDLP, UUP & DUP & DUP \\
\hline N & Y & Y & $N$ & Y & $56(18,28)$ & SF, OC, UUP & DUP & DUP \\
\hline$N$ & Y & $Y$ & $N$ & $N$ & $46(18,28)$ & DUP, OC, SDLP & DUP & DUP \\
\hline N & Y & $N$ & $Y$ & Y & $54(0,44)$ & DUP, UUP & DUP & DUP \\
\hline$N$ & Y & $N$ & $N$ & Y & $38(0,28)$ & DUP, UUP & DUP & DUP \\
\hline N & Y & N & Y & $N$ & $44(0,44)$ & DUP, UUP & DUP & DUP \\
\hline$N$ & Y & $N$ & $N$ & $N$ & $28(0,28)$ & DUP & DUP & - \\
\hline N & N & Y & Y & Y & $44(18,16)$ & DUP. SF & - & - \\
\hline$N$ & $N$ & Y & Y & $N$ & $34(18,16)$ & DUP, SF & - & - \\
\hline N & N & Y & $N$ & Y & $28(18,0)$ & DUP, SF & - & - \\
\hline$N$ & $N$ & $Y$ & $N$ & $N$ & $18(18,0)$ & - & - & - \\
\hline N & $N$ & $N$ & Y & Y & $26(0,16)$ & DUP & - & - \\
\hline$N$ & N & $N$ & $N$ & $Y$ & $10(0,0)$ & - & - & - \\
\hline$N$ & $N$ & $N$ & Y & $N$ & $16(0,16)$ & - & - & - \\
\hline$N$ & $N$ & N & $N$ & $N$ & $0(0,0)$ & - & - & - \\
\hline
\end{tabular}

